\title{
Rehabilitasi Medik pada Pasien Coronavirus Disease 2019
}

\author{
Mercy C. K. Parauba, ${ }^{1}$ Joudy Gessal, ${ }^{2}$ Christopher Lampah ${ }^{2}$
}

\author{
1Program Studi Pendidikan Dokter Fakultas Kedokteran Universitas Sam Ratulangi, Manado, \\ Indonesia. \\ ${ }^{2}$ Bagian Ilmu Kedokteran Fisik dan Rehabilitasi Fakultas Kedokteran Universitas Sam Ratu- \\ langi, Manado, Indonesia \\ Email: mercychristly@gmail.com
}

\begin{abstract}
COVID-19 could cause respiratory, physical and psychological dysfunctions. These dysfunctions reduce the patient's functional capacity ultimately. Changes in physical function over a period of hospitalizations and critical illness are more common occurr in patients with more severe or pre-existing disease comorbidities which often lead to mobility disabilities and restrictions in activities of daily life. Physical medicine and medical rehabilitation play an important role in increasing the functional capacity of COVID-19 patients. This study was aimed to evaluate the rehabilitation of COVID-19 patients. This was a literature review study using databases of Clinical Key, Web of Science, Pub Med, and Google Schoolar. The keywords used were rehabilitation COVID-19 OR rehabilitation SARS-CoV-2. Based on inclusion and exclusion criteria, eight literatures were selected. The result showed that early rehabilitation should be granted to inpatients with COVID-19. Patients with restricted mobility due to quarantine or lockdown should receive exercise programs to reduce the risk of frailty, sarcopenia, cognitive decline, and depression. Telerehabilitation may represent the first option for individuals at home. In conclusion, proper rehabilitation can reduce the consequences of decreasing functional capacity.
\end{abstract}

Keywords: rehabilitation; COVID-19 patients

\begin{abstract}
Abstrak; COVID-19 dapat menyebabkan disfungsi pernapasan, fisik, dan psikologis yang menurunkan kapasitas fungsional pasien. Perubahan fungsi fisik selama periode rawat inap dan penyakit kritis lebih umum dialami oleh pasien dengan penyakit COVID-19 yang lebih parah atau disertai komorbiditas dan dapat berakibat cacat mobilitas dan pembatasan dalam aktivitas kehidupan sehari-hari. Kedokteran fisik dan rehabilitasi medik memiliki peran penting dalam meningkatkan kapasitas fungsional pasien COVID-19. Penelitian ini bertujuan untuk mengetahui peran rehabilitasi medik pada pasien COVID-19. Jenis penelitian ialah literature review menggunakan database Clinical Key, Web of Science, PubMed, dan Google Scholar. Kata kunci yang digunakan yaitu rehabilitasi COVID-19 OR rehabilitasi SARS-CoV-2. Seleksi data berdasarkan kriteria inklusi dan ekslusi mendapatkan delapan literatur. Hasil penelitian menunjukkan bahwa rehabilitasi dini harus diberikan kepada pasien rawat inap dengan COVID-19. Pasien dengan mobilitas terbatas karena karantina atau lockdown harus menerima latihan program untuk mengurangi risiko kelemahan, sarkopenia, penurunan kognitif, dan depresi. Telerehabilitasi mungkin merupakan pilihan pertama bagi individu di rumah. Simpulan penelitian ini ialah rehabilitasi dini yang tepat dapat mengurangi konsekuensi penurunan kapasitas fungsional.
\end{abstract}

Kata kunci: rehabilitasi; pasien COVID-19

\section{PENDAHULUAN}

Coronavirus Disease 2019 atau biasa disebut COVID-19 adalah infeksi saluran pernapasan akibat virus korona baru yaitu
Severe Acute Respiratory Syndrom Coronavirus 2 (SARS-CoV-2) yang awalnya disebut Novel Coronavirus (2019-nCoV). Pada tanggal 31 Desember 2019, WHO China 
Country Office melaporkan kasus pneumonia yang tidak diketahui penyebabnya di Kota Wuhan, Provinsi Hubei, Cina. Pada tanggal 30 Januari 2020 WHO menetapkan kejadian tersebut sebagai Kedaruratan Kesehatan Masyarakat yang Meresahkan Dunia (KKMMD)/Public Health Emergency of International Concern (PHEIC). Pada tanggal 28 Februari 2020, WHO menaikkan ancaman epidemi COVID-19 ke level "sangat tinggi". Pada tanggal 11 Maret, jumlah kasus COVID-19 di luar China meningkat 13 kali lipat dan jumlah kasus negara yang terlibat telah tiga kali lipat dengan lebih dari 118.000 kasus di 114 negara dan lebih dari 4.000 kematian, akhirnya tingkat infeksi COVID-19 dinyatakan sebagai pandemi oleh WHO. ${ }^{1}$

Infeksi berkisar dari asimtomatik hingga parah. Gejala biasanya berupa demam, batuk, dan (dalam kasus sedang hingga berat) dispnea. Penyakit dapat berkembang selama seminggu atau lebih dari ringan sampai parah. Kerusakan organ bisa terjadi secara tiba-tiba. ${ }^{2}$ Rerata masa inkubasi ialah 5-6 hari dengan masa inkubasi terpanjang 14 hari. Pada kasus COVID-19 yang berat dapat terjadi disfungsi pernapasan seperti pneumonia, sindrom pernapasan akut, gagal ginjal, dan bahkan kematian. ${ }^{3}$

COVID-19 merupakan penyakit infeksi pernapasan yang sangat menular, menyebabkan komplikasi pulmonar, kardiovaskular, dan muskular yang berakibat terjadinya berbagai disfungsi organ yang pada akhirnya dapat menurunkan kapasitas fungsional pasien. Sebagai suatu bidang spesialisasi, kedokteran fisik dan rehabilitasi medik dengan filosofi fungsi, memiliki peran penting dalam meningkatkan kappasitas fungsional pasien COVID-19. ${ }^{4}$

Rehabilitasi merupakan intervensi penting bagi pasien klinis sekaligus penyembuhannya. ${ }^{5}$ Tujuan rehabilitasi pada pasien COVID-19 ialah untuk memperbaiki gejala dispnea, meredakan kecemasan, mengurangi komplikasi, meminimalkan kecacatan, memelihara fungsi, dan meningkatkan kualitas hidup. Rehabilitasi selama penanganan akut COVID-19 harus dipertimbangkan jika memungkinkan dan aman serta dapat mencakup nutrisi, jalan napas, postur tubuh, teknik pembersihan, suplementasi oksigen, latihan pernapasan, peregangan, terapi manual, dan aktivitas fisik. Mengingat kemungkinan kecacatan jangka panjang, rehabilitasi dapat dipertimbangkan pada semua pasien yang dirawat di rumah sakit dengan COVID-19. ${ }^{6}$

Berdasarkan latar belakang yang telah dipaparkan maka penulis terdorong untuk membahas dan menelaah hal-hal berkaitan dengan rehabilitasi pasien Covid-19 pada era pandemi Covid-19 ini.

\section{METODE PENELITIAN}

Penelitian ini merupakan suatu literature review. Data penelitian ini berupa artikel atau jurnal ilmiah bereputasi baik nasional maupun internasional dengan tema yang sudah ditentukan. Pencarian data menggunakan database dengan kriteria yang ditentukan yaitu Pubmed, Web of Science, Clinical Key, dan Google Scholar. Kata kunci yang digunakan dalam pencarian artikel yaitu rehabilitation COVID-19 OR rehabilitation SARS-CoV-2. Penelusuran jurnal publikasi pada database Pubmed, Web of Science, Google Scholar, dan Clinical Key dengan menggunakan kata kunci yang dipilih yaitu rehabilitation COVID-19 OR rehabilitation SARS-CoV-2 dalam berbagai bentuk variasi dan terjemahan. Artikel atau jurnal yang sesuai dengan kriteria inklusi dan ekslusi diambil untuk selanjutnya dianalisis. Penelitian ini menggunakan literatur terbitan tahun 2020 yang dapat diakses full-text dalam format pdf.

\section{HASIL PENELITIAN}

Pada penelitian ini didapatkan literatur sebanyak 458 Google scholar, 175 Web of Science, 148 Pubmed, 81 Clinical Key yang sesuai dengan kata kunci tersebut. Hasil pencarian yang sudah didapatkan kemudian dilakukan skrining berdasarkan judul yang sesuai dengan tema literature review dan didapatkan 51 buah. Selanjutnya 51 literatur diskrining abstrak dan full-text berdasarkan kriteria inklusi dan eklusi didapatkan 14 literatur, dan yang tidak sesuai dengan kriteria inklusi dilakukan eksklusi sebanyak 
enam, sehingga didapatkan delapan literatur full-text yang dilakukan review.

Delapan literatur yang memenuhi kriteria inklusi terdiri dari penelitian Boldrini et $\mathrm{al}^{7}$ di Itali, penelitian Chen et $\mathrm{al}^{8}$ di Cina, penelitian Koh et $\mathrm{al}^{9}$ di USA, penelitian Jiménez-Pavónet $\mathrm{al}^{10}$ di Spanyol, penelitian Jin et $\mathrm{al}^{11}$ di Cina, penelitian Lazzeri et al ${ }^{12}$ di Itali, penelitian McNeary et $\mathrm{al}^{13}$ di USA, dan penelitian Liu et $\mathrm{al}^{14}$ di Cina. Literatur yang dipakai melibatkan penelitian pada orang terinfeksi SARS-CoV-2. Jumlah sampel yang diambil dari kedelapan literatur berkisar ratusan sampel. Tabel 1 merangkum hasil kajian kedelapan literatur dalam penelitian ini.

Tabel 1. Literatur penelitian menurut penulis, negara, tujuan, populasi target, dan pengaturan

\begin{tabular}{|c|c|c|c|c|}
\hline $\begin{array}{l}\text { Penulis, } \\
\text { Negara }\end{array}$ & $\begin{array}{c}\text { Tujuan } \\
\text { Penelitian }\end{array}$ & $\begin{array}{c}\text { Populasi } \\
\text { Target }\end{array}$ & $\begin{array}{c}\text { Pengaturan } \\
\text { Target }\end{array}$ & Isi Utama \\
\hline $\begin{array}{l}\text { Boldrini } \\
\text { P et al, } \\
2020 .^{7} \\
\text { Itali }\end{array}$ & $\begin{array}{l}\text { Memberikan reko- } \\
\text { mendasi nasional } \\
\text { tentang kepedulian } \\
\text { terhadap rehabili- } \\
\text { tasi mengingat wa- } \\
\text { bah COVID-19 di } \\
\text { Italia }\end{array}$ & $\begin{array}{l}\text { Pasien COVID- } \\
19 \text { yang membu- } \\
\text { tuhkan rehabi- } \\
\text { litasi intervensi } \\
\text { dan rehabilitasi } \\
\text { profesional }\end{array}$ & \begin{tabular}{l}
\multicolumn{3}{c}{ Bangsal perawat- } \\
an akut, rawat \\
inap dan rawat \\
jalan, fasilitas re- \\
habilitasi dan \\
lingkungan \\
rumah
\end{tabular} & $\begin{array}{l}\text { SIMFER memberikan rekomendasi } \\
\text { untuk perawatan pasien COVID-19 } \\
\text { (memastikan intervensi yang mema- } \\
\text { dai dalam perawatan akut, pengaturan } \\
\text { rehabilitasi rawat inap, rawat jalan, } \\
\text { dan pengaturan rehabilitasi berbasis } \\
\text { rumah), perlindungan pasien dan } \\
\text { profesional (mencegah penyebaran } \\
\text { file infeksi), dan aktivasi layanan } \\
\text { dukungan jarak jauh "Tele- } \\
\text { rehabilitasi" (memberikan informasi } \\
\text { dan nasehat kepada orang dengan } \\
\text { kondisi disabilitas) }\end{array}$ \\
\hline $\begin{array}{l}\text { Chen P } \\
\text { et al, } \\
2020 .^{8} \\
\text { Cina }\end{array}$ & $\begin{array}{l}\text { Menyediakan } \\
\text { rekomendasi } \\
\text { tentang pencegah- } \\
\text { an komplikasi aki- } \\
\text { bat karantina/ pem- } \\
\text { batasan mobilitas } \\
\text { berkepanjangan }\end{array}$ & $\begin{array}{l}\text { Orang-orang } \\
\text { yang dikaranti- } \\
\text { na di rumah atau } \\
\text { dengan dibatasi } \\
\text { mobilitas karena } \\
\text { lockdown }\end{array}$ & $\begin{array}{l}\text { Pengaturan } \\
\text { berbasis rumah }\end{array}$ & $\begin{array}{l}\text { Ada alasan kesehatan yang kuat untuk } \\
\text { melanjutkan aktivitas fisik di rumah } \\
\text { agar tetap sehat dan menjaga keke- } \\
\text { balan fungsi sistem tubuh di ling- } \\
\text { kungan berisiko saat ini. Pelatihan } \\
\text { fisik di rumah hendaknya mencakup } \\
\text { penguatan dan latihan keseim- } \\
\text { bangan, peregangan atau kombinasi. }\end{array}$ \\
\hline $\begin{array}{l}\text { Koh C-H } \\
\text { G et al, } \\
20209^{9} \\
\text { USA }\end{array}$ & $\begin{array}{l}\text { Mengingatkan dan } \\
\text { menyediakan sara- } \\
\text { na untuk rehabili- } \\
\text { tasi komunitas se- } \\
\text { hingga mengerti } \\
\text { apa yang harus } \\
\text { dilakukan untuk } \\
\text { menghadapi pan- } \\
\text { demi COVID-19 }\end{array}$ & $\begin{array}{l}\text { Pasien COVID- } \\
19 \text { yang mem- } \\
\text { butuhkan reha- } \\
\text { bilitasi intervensi } \\
\text { dan rehabilitasi } \\
\text { profesional }\end{array}$ & $\begin{array}{l}\text { Bangsal pera- } \\
\text { watan akut, } \\
\text { rawat inap dan } \\
\text { rawat jalan, fasi- } \\
\text { litas rehabilitasi } \\
\text { dan lingkungan } \\
\text { rumah }\end{array}$ & $\begin{array}{l}\text { Rehabilitasi penderita COVID-19 } \\
\text { yang berisiko lebih parah dan fatal. } \\
\text { Saran praktis meliputi: } \\
\text { - lanjutkan latihan di rumah yang telah } \\
\text { ditentukan sebelumnya dan melan- } \\
\text { jutkan kehadiran di pusat rehabilitasi } \\
\text { jika dalam keadaan baik tetapi } \\
\text { dengan langkah-langkah pengenda- } \\
\text { lian infeksi yang ditingkatkan } \\
\text { - Rehabilitasi tele adalah pilihan } \\
\text { pertama bagi orang yang mampu } \\
\text { melakukan rehabilitasi di rumah } \\
\text { dengan bimbingan dari Spesialis } \\
\text { KFR } \\
\text { - Gejala demam dan flu harus dipan- } \\
\text { tau untuk pasien yang membutuhkan } \\
\text { rehabilitasi berbasis pusat atau rawat } \\
\text { inap } \\
\text { - pasien bergejala harus dikarantina } \\
\text { dan diuji untuk virus korona, dan } \\
\text { diisolasi dan diobati jika positif }\end{array}$ \\
\hline $\begin{array}{l}\text { Jiménez- } \\
\text { Pavón D } \\
\text { et al, }\end{array}$ & $\begin{array}{l}\text { Memromosikan } \\
\text { aktivitas fisik dan } \\
\text { olahraga untuk me- }\end{array}$ & $\begin{array}{l}\text { Orang-orang } \\
\text { yang dikarantina } \\
\text { di rumah atau }\end{array}$ & $\begin{array}{l}\text { Pengaturan } \\
\text { berbasis rumah }\end{array}$ & $\begin{array}{l}\text { Program olahraga yang tepat mung- } \\
\text { kin dapat melawan hal negatif seperti } \\
\text { konsekuensi dari beberapa penyakit }\end{array}$ \\
\hline
\end{tabular}


86 Medical Scope Journal (MSJ), Volume 3, Nomor 1, Juli-Desember 2021, hlm. 83-89

\begin{tabular}{llll}
\hline $2020 .^{10}$ & lawan & konse- & dengan dibatasi \\
Spanyol & kuensi karantina & mobilitas karena \\
& COVID-19 pada & lockdown \\
& orang tua
\end{tabular}

Jin X et Untuk mengemal, bangkan Core Out-

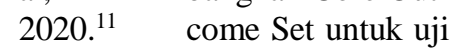
Cina klinis pada COVID-19 (COSCOVID)

$\begin{array}{ll}\text { Lazzeri } & \text { Untuk berbagi } \\ \text { M et al, } & \text { informasi dengan } \\ 2020 .^{12} & \text { terapis fisik yang } \\ \text { Itali } & \text { terlibat pengelo- } \\ & \text { laan pasien yang } \\ & \text { terkena COVID-19 } \\ & \text { akut secara berta- } \\ & \text { hap di seluruh } \\ & \text { dunia }\end{array}$

Pasien COVID- Bangsal perawat19 an akut, rawat inap dan rawat jalan, fasilitas rehabilitasi dan lingkungan rumah (diabetes, hipertensi, penyakit kardiovaskular, penyakit pernapasan), hingga mengurangi resiko kelemahan, sarkopenia, dan demensia, dan untuk mencegah efek psikologis karantina. Program rehabilitasi multikomponen, termasuk aerobik, resistensi, keseimbangan, koordinasi dan mobilitas latihan, selama 5-7 hari/minggu, dengan intensitas sedang dapat mempertahankan status kesehatan yang memadai untuk orang yang lebih tua. COS-COVID terdiri dari 8 ukuran hasil yang berbeda untuk digunakan dalam berbagai skenario infeksi COVID-19:

1.waktu untuk 2019-nCoV RT -PCR negatif (ringan, biasa dan kasus yang parah)

2.skor gejala klinis (kasus biasa)

3.lama tinggal di rumah sakit (kasus biasa dan parah)

4.kejadian gabungan (jumlah total pasien yang didiagnosis sebagai kematian yang parah, kritis dan semua penyebab), (biasa dan kasus yang parah)

5.PaO2/FiO2 (kasus parah)

6.durasi ventilasi mekanis, (kasus yang parah)

7.kematian karena semua penyebab (kasus kritis)

8. fungsi paru (fase rehabilitasi)

Pasien COVID- Acute care - Nasihat berikut diberikan kepada $19 \quad$ setting ahli terapi fisik yang terlibat dalam manajemen pasien yang terkena COVID-19 dalam tahap akut:

- memantau kondisi klinis dengan cermat dan mempersiapkan untuk ventilasi mekanis invasif;

- untuk mempertimbangkan kelayakan setiap perlakuan, berdasarkan peralatan yang tersedia, dan mengadopsi strategi bersama yang dilakukan oleh tim multidisiplin;

- untuk memantau kondisi klinis pasien setelah perubahan postur tubuh, karena peristiwa ini dapat memengaruhi secara tiba-tiba kemampuan pasien untuk bertukar gas;

- untuk mengurangi manuver yang tidak perlu, khususnya prosedur yang dapat menurunkan tekanan akhir ekspirasi dan menyebabkan de-rekrutmen paru;

- melakukan mobilisasi pasif sedini mungkin

- hindari gejala sisa imobilisasi; 


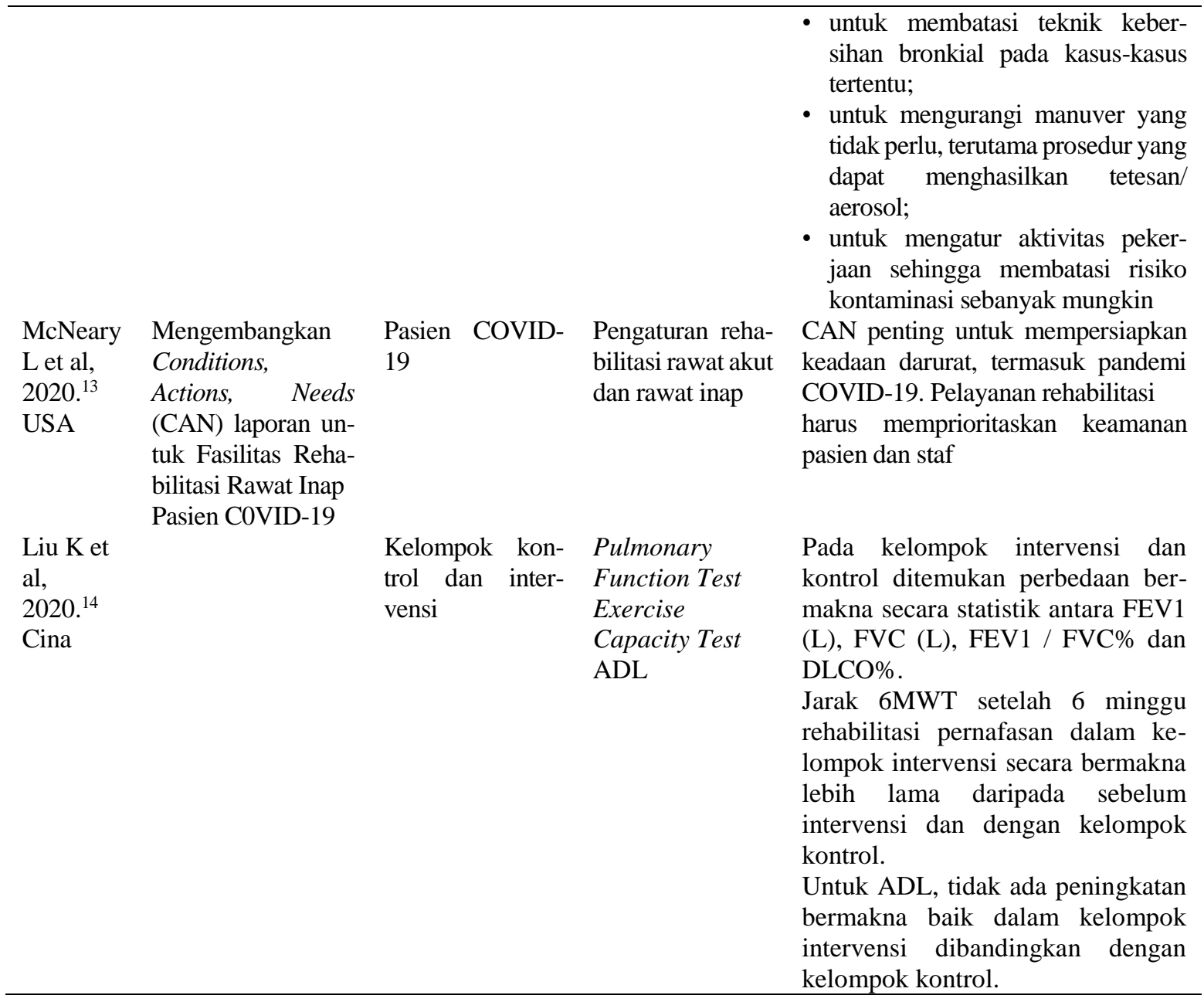

RT-PCR: reverse transcriptase-polymerase chain reaction; $\mathrm{PaO}_{2} / \mathrm{FiO}_{2}$ : ratio between partial pressure of oxygen in arterial blood and fraction of inspired oxygen; ADL: Activity of Daily Living; 6MWT: 6 Minute Walk Test

Semua artikel yang dipilih berkaitan dengan rehabilitasi yang baru muncul karena kebutuhan pandemi COVID-19. Enam literatur difokuskan pada kebutuhan khusus pasien COVID-19, sedangkan dua literatur mempertimbangkan peningkatan risiko kesehatan orang yang dikarantina dan subjek dibatasi di rumah karena lockdown. Nasihat untuk perawatan kesehatan menyangkut pengaturan yang berbeda, termasuk bangsal perawatan akut $(\mathrm{N}=6)$, fasilitas rehabilitasi rawat inap $(\mathrm{N}=5)$, pelayanan rehabilitasi rawat jalan $(\mathrm{N}=5)$, dan rumah lingkungan $(\mathrm{N}=6)$. Wilayah geografis diwakili penulis sesuai dengan negara yang dilanda wabah COVID-19 sebagai yang pertama atau secara masif: empat artikel berasal dari Cina, dua dari Italia, dan dua dari Amerika Serikat. ${ }^{7-14}$

Kelompok pertama terutama terdiri dari panggilan untuk tindakan, atau peringatan untuk profesional rehabilitasi ten- tang cara menghadapi tantangan COVID19. ${ }^{8,10,14}$ Literatur pada kelompok ini membahas tentang apa yang harus dilakukan untuk membatasi penyebaran infeksi dan mengatur kembali kegiatan rehabilitasi rawat inap untuk meningkatkan kapasitas di rumah sakit akut. McNeary et $\mathrm{al}^{13}$ juga menyatakan harus waspada terhadap gejala sisa yang muncul akibat posisi selama ventilasi mekanis yang berkepanjangan, seperti sindrom ensefalopati, penyakit kritis miopati/ neuropati, dengan kontraktur dan luka plantar fleksi. Pasien mungkin menderita gangguan pernapasan yang parah dan tidak dapat mentolerir terapi intensif.

Kelompok kedua diwakili oleh literatur yang memberikan rekomendasi tentang intervensi spesifik yang akan diberikan dalam fase akut infeksi COVID-19. ${ }^{12}$ Lazzeri et al ${ }^{12}$ memberikan indikasi khusus kepada ahli terapi fisik tentang manajemen 
pasien yang terkena COVID-19 di bangsal akut, dengan fokus pada subjek yang gagal napas.

Kelompok ketiga membahas kebutuhan orang yang dikarantina di rumah atau dengan mobilitas terbatas karena lockdown. ${ }^{8,10}$ Chen et $\mathrm{al}^{8}$ memfokuskan pada subjek yang sehat dan merekomendasikan mereka agar tetap aktif untuk menjaga respon imun dan terlindung dari infeksi, Jiménez-Pavón et al, ${ }^{10}$ mempertimbangkan kebutuhan orang tua, menggarisbawahi bahwa program olahraga yang tepat dapat menangkal konsekuensi negatif dari penyakit kronis, meninjau indikasi Pengobatan Tradisional Cina (TCM), menyarankan penggunaan TCM sebagai sarana untuk menurunkan demam, batuk, meludah, kelelahan dan kesulitan sehingga mengurangi resiko kelemahan, sarkopenia, dan demensia, serta mencegah efek psikologis karantina. Keduanya peneliti setuju tentang konten program rehabilitasi, yang harus mencakup pelatihan aerobik, ketahanan, keseimbangan, koordinasi dan mobilitas.

Terakhir ialah literatur oleh Jin et $\mathrm{al}^{11}$ yang menindaklanjuti hasil dari proses konsensus dengan dua survei Delphi, dan menyimpulkan untuk mengadopsi Core Outcome Set. Set ini terdiri dari delapan ukuran hasil yang berbeda yang digunakan dalam uji coba klinis untuk menguji kemanjuran strategi kesehatan pada fase akut atau fase rehabilitasi, dan pada subjek dengan derajat keparahan infeksi COVID-19 yang berbeda. Fungsi paru merupakan hasil yang disukai untuk menguji intervensi rehabilitasi.

\section{BAHASAN}

Sebagian besar literatur yang dieksplorasi ialah untuk mengingatkan para profesional rehabilitasi tentang kebutuhan mengatur ulang layanan rawat inap dan rawat jalan agar memastikan keselamatan pasien dan staf, sedangkan beberapa artikel yang berfokus pada risiko kesehatan akibat aturan pembatasan mobilitas yang diberlakukan pada orang tua atau orang dengan kondisi kronis.

Pesan utama dalam literatur ditujukan kepada pasien yang dirawat di rumah sakit karena infeksi COVID-19 dan orang yang dikarantina di rumah atau dengan mobiitas terbatas karena lockdown. Bagi pasien yang dirawat di rumah sakit karena infeksi COVID-19: harus dipastikan intervensi yang memadai di bangsal akut, mengadopsi strategi bersama yang dilakukan oleh tim multidisiplin, memantau kondisi klinis pasien dengan hati-hati setelah perubahan postur karena kejadian ini dapat memengaruhi kemampuan tiba-tiba pasien untuk bertukar gas, mengurangi manuver yang tidak perlu, dan memeriksa efek samping yang ditentukan dengan posisi tengkurap yang berkepanjangan selama ventilasi; bahkan mobilisasi pasif harus dilakukan sedini mungkin untuk menghindari gejala sisa imobilisasi dan mengatur pekerjaan kegiatan sehingga membatasi risiko kontaminasi personel sebagai sebanyak mungkin. Bagi orang yang dikarantina di rumah atau dengan mobilitas terbatas karena lockdown harua dipastikan penyediaan program olahraga yang tepat dalam mengurangi risiko kelemahan, sarkopenia, demensia, dan untuk mencegah efek psikologis dari karantina. Program rehabilitasi multikomponen, termasuk aerobik, tahanan, keseimbangan, koordinasi dan latihan mobilitas, selama 5-7 hari/minggu, dengan intensitas sedang, disarankan untuk menjaga status kesehatan yang memadai pada orang tua. Pendekatan tele-rehabilitasi bagi yang mampu berolahraga di rumah di bawah bimbingan profesional rehabilitasi. ${ }^{7-14}$

\section{SIMPULAN}

Rehabilitasi dini harus diberikan pada pasien rawat inap dengan COVID-19. Individu dengan mobilitas terbatas karena karantina atau lockdown harus menerima latihan program untuk mengurangi risiko kelemahan, sarkopenia, penurunan kognitif, dan depresi. Telerehabilitasi mungkin merupakan pilihan pertama bagi orang-orang di rumah. Pembaruan lebih lanjut diperlukan untuk menggambarkan kecacatan yang muncul pada penyintas COVID-19 dan efek sampingnya pada kesehatan orang yang cacat kronis. 
Diperlukan peningkatan pengetahuan lewat edukasi dan promosi kesehatan oleh pemerintah kepada masyarakat mengenai bahaya infeksi COVID-19 salah satunya menurunkan kapasitas fungsional tubuh. Keterlibatan semua pihak, baik dari pelayanan kesehatan maupun masyarakat dalam menjaga kesehatan dengan melakukan gaya hidup sehat dan mematuhi protokol kesehatan COVID-19. Diperlukan penelitian lebih lanjut untuk memahami efek COVID-19 pada sistem fungsional tubuh dan menentukan apakah rehabilitasi medik dapat mendorong pemulihan pasca infeksi.

\section{Konflik Kepentingan}

Penulis menyatakan tidak terdapat konflik kepentingan dalam studi ini.

\section{DAFTAR PUSTAKA}

1. World Health Organization. Coronavirus Disease 2019 (COVID-19): Situation Report - 51 [Internet]. WHO website. Published 2020 March 11. [cited 2020 Sept 9]. Available from: https://www. who.int/docs/default-source/corona viruse/situation-reports/20200311sitrep-51-covid-19.pdf

2. Huang C, Wang Y, Li X, Ren L, Zhao J. Hu Y, et al. Clinical features of patients infected with the 2019 novel corona virus in Wuhan, China. Lancet 2020; 395:500-1.

3. Pedoman Pencegahan dan Pengendalian Coronavirus Disease (COVID-19) Revisi ke5. Jakarta: Kementerian Kesehatan Republik Indonesia, 2020; p. 17.

4. Tim Dosen Fakultas Kedokteran Unisba, Editor. Kopidpedia: Bunga Rampai Artikel Penyakit Virus Korona. Bandung: Pusat Penerbitan Universitas (P2U) Unisba, 2020; p. 93-104.

5. Zhao H-M, Xie, Y-X, Wang C. Recommendations for Respiratory Rehabilitation of COVID-19 in Adults]. Chinese Medical Journal. 2020;133(13):15951602

6. Wang TJ, Chau B, Lui M, Lam GT, Lin N, Humbert S. PM\&R and Pulmonary Rehabilitation for COVID-19. Wolters Kluwer Health, Inc. 2020. Available from: https://www.ncbi.nlm.nih.gov/ pmc/articles/PMC7315835/

7. Boldrini P, Bernetti A, Fiore P; SIMFER Executive Committee and SIMFER Committee for international affairs. Impact of COVID-19 outbreak on rehabilitation services and Physical and Rehabilitation Medicine (PRM) physicians' activities in Italy. An official document of the Italian PRM Society (SIMFER). Eur J Phys Rehabil Med. 2020;56(3):316-8.

8. Chen P, Mao L, Nassis GP, Harmer P, Ainsworth BE, Li F. Coronavirus disease (COVID-19): the need to maintain regular physical activity while taking precautions. J Sport Health Sci 2020;9(2):103-4.

9. Koh C-H G, Hoenig H. How should the rehabilitation community prepare for 2019-nCoV? Arch Phys Med Rehabil. 2020;101(6):1068-71.

10. Jiménez-Pavón D, Carbonell-Baeza A, Lavie CJ. Physical exercise as therapy to fight against the mental and physical consequences of COVID-19 quarantine: special focus in older people. Prog Cardiovasc Dis. 2020;63(3):386-8.

11. Jin X, Pang B, Zhang J, Liu Q, Yang Z, Feng $\mathrm{J}$, et al. Core Outcome Set for Clinical Trials on Coronavirus Disease 2019 (COS-COVID). Engineering (Beijing) 2020;6(10):1147-52.

12. Lazzeri M, Lanza A, Bellini R, Bellofiore A, Cecchetto S, Colombo A, et al. Respiratory physiotherapy in patients with COVID-19 infection in acute setting: a position paper of the Italian Association of Respiratory Physiotherapists (ARIR). Monaldi Arch Chest Dis. 2020;90(1). Doi: 10.4081/monal di.2020.1285.

13. McNeary L, Maltser S, Verduzco-Gutierrez M. Navigating coronavirus disease 2019 (Covid-19) in psychiatry: A CAN report for inpatient rehabilitation facilities. PM R 2020;12(5):512-5.

14. Liu K, Zhang W, Yang Y, Zhang J, Li Y, Chen $Y$, et al. Respiratory rehabilitation in elderly patients with COVID-19: A randomized controlled study. Complement Ther Clin Pract. 2020;39:101166. 